\title{
EFFICIENCIES OF VARIOUS FORMS OF HERBALS AND SPICES IN MEAT MARINATION ON PRODUCT QUALITY AND SOME HETEROCYCLIC AROMATIC AMINE (HCA) COMPOUNDS
}

\author{
Gulen Yildiz Turp \\ Department of Food Engineering \\ Ege University, Izmir, Turkey
}

\author{
Berna Çapan \\ Department of Food Engineering \\ Ege University, Izmir, Turkey
}

\begin{abstract}
Conservatively, meat has been marinated to improve flavor, tenderness, and increase meat shelf life. Beneficial effects of marination on meat texture include a juicier texture and decrease of cooking loss. Another aspect of marination is the increase of yield of the raw meat, which can provide benefits to the producer and the consumer. Besides that in recent years, it was revealed that some of the herbals and spices used in marinades have potential to inhibit the occurrence of heterocyclic aromatic amines (HCA) in meat. Cooking of meat generates these heat induced toxicants HCA's which are strongly mutagenic and carcinogenic. Marinades are water-based solutions that can include salt, organic acids, oil, herbs, spices, sugar, binders, antimicrobial agents and aroma enhancers. Natural additives were increasingly demanded for meat marination since concern over the safety of synthetic additives has arisen in recent years. Herbs and spices such as thyme, garlic, ginger extract have capability to prevent oxidation and microbiological spoilage of food, possibly better than many presently used synthetic antioxidants. Also preventing the occurrence of HCA's is the another important function of some of them determined in recent years. Various forms of herbals and spices such as essential oils, organic acids, powder and extract forms are used in meat marination and efficiencies of them were detected as different.
\end{abstract}

Keywords - Marination, Herbal, Spices, Meat Quality, Heterocyclic aromatic amine

\section{INTRODUCTION}

Marinating is a process of incorporating a liquid solution, often called a marinade, to improve flavour, texture and juiciness to muscle foods. A marinade may contain any materials added to enhance the eating quality and appearance of the finished product. These includes; salt, organic acids, water, seasoning, spices, sugar, binders, antimicrobial agents and aroma enhancers [1]. Marinade solutions may also include natural or dried ingredients, herbs and other extracts. Spices and herbs, added in marinades significantly enhance meat safety and controlled or minimized lipid oxidation [2].

At present, meat industry uses chemical additives to prevent growth of food-borne pathogens and extend the shelf life of refrigerated storage of the products. Since concern over the safety of chemical additives has arisen in recent years, consumers increasingly demand use of natural products as alternative preservatives in foods [3].

The application of extracts from fruits, herbs and plants is of increasing interest given the consumer's demand in so called "natural additives": those naturally present in plants and to which numerous effects have been ascribed [4].

Marinating can reduce the formation of some carcinogen compounds such as heterocyclic aromatic amines (HCA) which occur during the cooking process. Addition of compounds, having antioxidant properties during meat marinating was claimed to be an effective method to reduce HCA in foods [5]. Marinades can act as a barrier to avoid the direct contact of flame with the meat and substantial reductions in the concentrations of MeIQ, PhIP, Di- MeIQx, IQ, IQx, and Norharman were reported in grilled chicken, grilled beef, and deep fried lamb meat [6]. HCA are formed on the surface of meat products through the Maillard reaction due to heat treatment, which involves creatinine, free amino acids and reducing sugars (glucose and fructose, directly or via hydrolysis of sucrose) as precursors [6]. The formation of $\mathrm{HCA}$ is a redox reaction, and antioxidants have the potential to reduce the formation of the HCA [7]. Herbs and spices, naturally rich in phenolic compounds, present high antioxidant activity toward free radicals and may provide easy-to-use tools for reduction of HCA dietary intake, when meats are pretreated or cooked with these ingredients [8]. 


\section{International Journal of Engineering Applied Sciences and Technology, 2019 \\ Vol. 4, Issue 8, ISSN No. 2455-2143, Pages 63-71 \\ Published Online December 2019 in IJEAST (http://www.ijeast.com)}

\section{USAGE OF ESSENTIAL OILS IN MEAT MARINATION}

The demand for natural alternatives to synthetic additives increases and the replacement, in foodstuffs, of synthetic antimicrobials such as sorbate and benzoate by essential oils (EOs) is getting considerable attention [9]. The modern trends in nutrition suggest the limitation of synthetic food additives or the substitution with natural ones [3].

Over the last years, various studies have focused on use of EOs in foods in order to either extend the shelf-life or improve the food safety of products [10]. Essential oils of both plants possess numerous biological activities such as antibacterial, antifungal, antiviral and antioxidative $[11,12]$.

The active compounds in EOs with antimicrobial properties can be divided as: terpenes, terpenoids, phenylpropenes and others. There are indications that the microbial shelf life of certain meat and fish products can be increased by treatment of the foodstuff with certain EOs, and often EO from Origanum vulgare or Thymus vulgaris has been studied in that context because they contain the antimicrobial compounds thymol and carvacrol [9].

Particular interest has been focused on the potential application of plant essential oils as safer additives for meat. Several investigations have confirmed the antimicrobial action of essential oils against foodborne pathogens and spoilage bacteria in synthetic media, food systems and real foods. Higher concentrations of essential oils are needed to achieve the same effect in foods as in synthetic media. However, these higher concentrations needed to inhibit spoilage and pathogen bacteria in food matrixes could often exceed the flavor threshold acceptable to consumers [3].

Results of the studies on the use of essential oils in meat and meat products are given in Table 1 .

Table 1 Application of essential oils in meat marination

\begin{tabular}{|c|c|c|c|}
\hline Essential oils & $\begin{array}{c}\text { Meat/Meat } \\
\text { Product } \\
\text { Tested }\end{array}$ & Results & Reference \\
\hline $\begin{array}{l}\text { Essential oils } \\
\text { (carvacrol and } \\
\text { thymol, added } \\
\text { at } 0.4 \text { and } \\
0.8 \% \mathrm{v} / \mathrm{w})\end{array}$ & -Chicken & $\begin{array}{l}\text { - Chicken was } \\
\text { marinated at } 4^{\circ} \mathrm{C} \\
\text { for } 24 \text { hours. } \\
\text { - Carvacrol and } \\
\text { thymol controlled } \\
\text { the growth of } \\
\text { spoilage } \\
\text { microorganisms in } \\
\text { marinated chicken } \\
\text { meat. }\end{array}$ & [10] \\
\hline
\end{tabular}

\begin{tabular}{|c|c|c|c|}
\hline  & -Beef & $\begin{array}{l}\text { - Beef was marinated } \\
\text { at } 4^{\circ} \mathrm{C} \text { for } 24 \text { hours. } \\
\text { - Basic red wine } \\
\text { marinades and the } \\
\text { ones containing } \\
\text { each EO or their } \\
\text { combination } \\
\text { remarkably } \\
\text { decreased the } \\
\text { counts of all } \\
\text { monitored groups } \\
\text { comparing to saline } \\
\text { control. } \\
\text { The most } \\
\text { pronounced effect } \\
\text { was obtained with } \\
\text { the marinade } \\
\text { containing EOs } \\
\text { mixture. } \\
\text { For all monitored } \\
\text { bacteria, the } \\
\text { bactericidal effect } \\
\text { during marination } \\
\text { was followed by } \\
\text { bacteriostatic effect } \\
\text { during subsequent } \\
\text { meat storage. }\end{array}$ & [12] \\
\hline $\begin{array}{l}\text { Essential oils } \\
\text { (EOs) from; } \\
\text { - Oreganum } \\
\text { compactum } \\
\text { (oregano) }(1 \%) \\
\text { - Cinnamomum } \\
\text { zeylanicum } \\
\text { (cinnamon) } \\
(1 \%) \\
\text { - Thymus zygis } \\
\text { ct. Thymol } \\
\text { (thyme) (1\%) }\end{array}$ & \begin{tabular}{|l} 
- Pork filet \\
- Pork \\
bacon \\
- Chicken \\
filets \\
- Chicken \\
skin
\end{tabular} & $\begin{array}{l}\text { - The growth of } \\
\text { yeasts and molds } \\
\text { was inhibited by } \\
\text { immersion of all } \\
\text { food matrices in } 1 \\
\text { w/w \% cinnamon } \\
\text { EO. } \\
\text { - Use of (1 w/w \% } \\
\text { for all EO) } \\
\text { cinnamon EO led to } \\
\text { microbial shelf life } \\
\text { increase of pork } \\
\text { filet and pork } \\
\text { bacon. } \\
\text { Oregano } \\
\text { increased the } \text { EO } \\
\text { life of pork and } \\
\text { thyme EO of pork } \\
\text { filet. } \\
\text { Sensorial properties } \\
\text { of the meat were } \\
\text { inevitably affected } \\
\text { when the necessary } \\
\text { EO concentrations } \\
\text { to extend the } \\
\text { microbial shelf life } \\
\text { were applied. }\end{array}$ & [9] \\
\hline
\end{tabular}




\begin{tabular}{|c|c|c|c|}
\hline $\begin{array}{l}\text { Thyme and } \\
\text { orange } \\
\text { essential oils } \\
\text { (EO) }(1: 1)\end{array}$ & $\begin{array}{l}\text { - Chicken } \\
\text { breast } \\
\text { and wing }\end{array}$ & $\begin{array}{l}\text { - Tumbled with a lab- } \\
\text { scale tumbler at } 20 \\
\text { rpm for } 20 \text { min at } \\
\text { room temperature. } \\
\text { - Lower purge loss } \\
\text { (breast and wing). } \\
\text { - Higher } a^{*} \text { and } b^{*} \\
\text { values (wing). } \\
\text { - Lower shear force } \\
\text { (wing). } \\
\text { - Positive effect on } \\
\text { breast and wing } \\
\text { lipid oxidation. }\end{array}$ & [13] \\
\hline $\begin{array}{l}\text { Oregano oil } \\
\text { (Origanum } \\
\text { heracleoticum } \\
\text { L.) }(1.25 \%, \\
0.625 \% \text { and } \\
0.156 \%)\end{array}$ & - Chicken & $\begin{array}{l}\text { - All samples were } \\
\text { stored at } 4^{\circ} \mathrm{C} \text {. } \\
\text { Sampling was } \\
\text { carried out every } \\
24 \mathrm{~h} \text { during } 7 \text { days. } \\
\text { - Enhanced the shelf- } \\
\text { life for two days of } \\
\text { the samples with } \\
0.625 \% \text { oregano oil } \\
\text { and three days of } \\
\text { the samples with } \\
1.25 \% \text { oregano oil. }\end{array}$ & [3] \\
\hline
\end{tabular}

\section{USAGE OF SPICE AND HERBAL ADDITIVES IN MEAT MARINATION}

The interest in spices and aromatic herbs has recently increased because of their ability to prevent oxidation and microbiological spoilage of food, possibly better than many currently used synthetic antioxidants [13]. The antimicrobial properties of marinades are due to lowering of the $\mathrm{pH}$, lowering of the water activity and addition of certain herbs and antimicrobial food additives [9].

It is known that fruit extracts and pulps can be used as natural antioxidants in meat products. Fruits are known to contain antioxidants such as fat-soluble vitamins, carotenoids, tocopherols, flavanoids, and water-soluble vitamin C. Bioactive ingredients and dietary fiber, which are highly found in fruit products, can also be used as an antimicrobial, coloring, flavoring and thickening agent [25].

Spices and herbs are excellent sources of antioxidants. Spices are used as ingredients, typically in relatively small amounts in recipes and formulations such as spice mixes and marinating sauces to enhance food flavor. It is expected that these marinating sauces should be excellent sources of antioxidants, since their main ingredients are derived from herbs and spices. However, these sauces undergo different processing methods during their production and are often used to marinate foods for different periods of time, and are exposed to various methods of cooking. All of these factors may potentially alter the antioxidant status of sauces significantly, and consequently the amount of antioxidants available to the consumer [15].

Several studies have shown that natural antioxidants in the form of spices, berries, wine or beer can reduce the formation of HCA in beef, chicken and pork. As previous research has demonstrated, pork chops, in particular, are often marinated before barbecuing, and there exists the potential to produce marinades using antioxidant herbs and berries, thus reducing the risk of formation of HCAs during barbecuing. Most of the studies investigating the effects of different natural antioxidants have used either a pure spice or berries or an extract of these in the experiments. Furthermore, numerous investigations have focused on the ability of the active compound to reduce HCAs and have overlooked the sensory quality of the marinated meat. However, it seems important to combine the chemical analysis of the effect of the compounds with a sensory and consumer study to evaluate the gastronomic value [7].

Results of the studies on the use of spice and herbal additives in meat and meat products are given in Table 2.

Table 2 Application of spice and herbal additives in meat marination

\begin{tabular}{|c|c|c|c|}
\hline $\begin{array}{l}\text { Spice and Herbal } \\
\text { Additives }\end{array}$ & $\begin{array}{c}\text { Meat/Meat } \\
\text { Product } \\
\text { Tested } \\
\end{array}$ & Results & References \\
\hline $\begin{array}{ll} & \text { Carbernet } \\
& \text { (CAB) } \\
- & \text { Tempranillo } \\
& \text { (TEM) } \\
- & \text { Isabel (ISA) } \\
- & \text { Control } \\
& (300 \mathrm{~mL} \\
\text { dealcoholized } \\
\text { wine/kg meat) }\end{array}$ & - Beef & $\begin{array}{l}\text { - Beef was marinated } \\
\text { for } 48 \text { hours at } 4^{\circ} \mathrm{C} \text {. } \\
\text { - CAB and TEM were } \\
\text { more effective } \\
\text { against lipid } \\
\text { oxidation. } \\
\text { - The lower Warner } \\
\text { Bratzler shear force } \\
\text { values in beef steaks } \\
\text { marinated with ISA. } \\
\text { - The particular } \\
\text { phenolic composition } \\
\text { of ISA wine and its } \\
\text { high content in } \\
\text { organic acids, may } \\
\text { explain its effects } \\
\text { against } \\
\text { Enterobacteriaceae } \\
\text { while sugars may } \\
\text { have promoted the } \\
\text { growth of lactic-acid } \\
\text { bacteria in beef } \\
\text { marinated with CAB } \\
\text { and TEM. }\end{array}$ & [4] \\
\hline
\end{tabular}


Published Online December 2019 in IJEAST (http://www.ijeast.com)

\begin{tabular}{|c|c|c|c|c|c|c|c|}
\hline $\begin{array}{l}\text { - Marinade }(16 \mathrm{~g} \\
\text { papaya leave } \\
\text { extract or } \\
\text { commercial } \\
\text { bromelain, } 2.5 \\
\mathrm{~g} \text { salt, } 2.5 \mathrm{~g} \\
\text { minced garlic, } \\
2.5 \mathrm{~g} \text { ground } \\
\text { black pepper, } \\
2.5 \mathrm{~g} \text { ground } \\
\text { cumin and } 2.5 \\
\mathrm{~g} \text { ground white } \\
\text { cumin) } \\
\text { - Control (2.5 g } \\
\text { salt, } 2.5 \\
\text { minced garlic, } \\
2.5 \mathrm{~g} \text { ground } \\
\text { black pepper, } \\
2.5 \mathrm{~g} \text { ground } \\
\text { cumin and } 2.5 \\
\mathrm{~g} \text { ground white } \\
\text { cumin) }\end{array}$ & - Chicken & $\begin{array}{l}\text { - Marinated chicken } \\
\text { was left in the } \\
\text { refrigerator for } \\
\text { overnight. } \\
\text { - } L^{*} \text { value, cooking } \\
\text { loss and shrinkage of } \\
\text { the marinated chicken } \\
\text { were higher than } \\
\text { control. } \\
a^{*}, b^{*} \text { values, protein } \\
\text { content, water- } \\
\text { holding capacity, } \\
\text { shear force, and } \\
\text { texture profile } \\
\text { analysis of the } \\
\text { marinated chicken } \\
\text { were lower than } \\
\text { control. }\end{array}$ & [14] & $\begin{array}{l}\text { - } \text { Table sugar } \\
(10 \mathrm{~g}), \text { brown } \\
\text { sugar (10.3g), } \\
\text { and honey } \\
(14.7 \mathrm{~g}) \text { with } \\
\text { the addition of } \\
\text { tamarind, } \\
\text { lemon, lime, } \\
\text { and calamansi }\end{array}$ & $\begin{array}{l}\text { - Grilled } \\
\text { chicken }\end{array}$ & 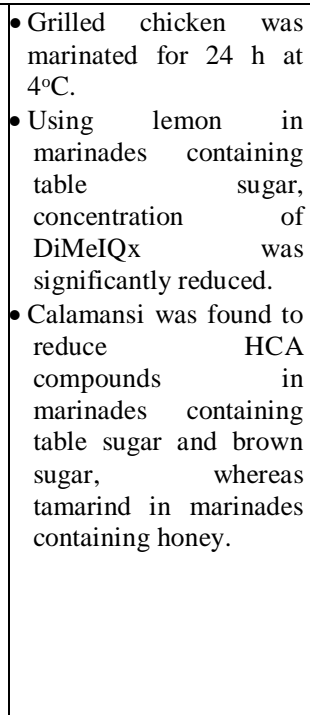 & [6] \\
\hline $\begin{array}{l}\text { - Oregano } \\
\text { - Acerola } \\
\text { - Dijon marinade } \\
\text { ( acerola, } \\
\text { sumac and } \\
\text { oregano ) }\end{array}$ & - Pork chops & $\begin{array}{l}\text { - All of the marinades } \\
\text { reduced the content } \\
\text { of MeIQx and } \\
\text { DiMeIQx, although } \\
\text { only with indirect } \\
\text { heat, while PhiP was } \\
\text { reduced using both } \\
\text { grilling methods. } \\
\text { - In particular the } \\
\text { content of Harman } \\
\text { and to a lesser extent } \\
\text { Norhaman was very } \\
\text { high in the Dijon- } \\
\text { marinated chops. }\end{array}$ & [7] &  & $\begin{array}{l}\text { - } \text { Beef } \\
\text { - Pork } \\
\text { - Mutton } \\
\text { - Chicken }\end{array}$ & $\begin{array}{l}\text {-Boiling meat }(98 \pm \\
\left.2^{\circ} \mathrm{C}\right) \text { with various } \\
\text { ingredients, including } \\
\text { soy sauce, sugar, rice } \\
\text { wine. } \\
\text { - Beef had the highest } \\
\text { content of total HCA } \\
\text { compared with pork, } \\
\text { mutton and chicken. } \\
\text { - Soy sauce contributed } \\
\text { to the formation of } \\
\text { HCA more greatly } \\
\text { than rock candy, soy } \\
\text { sauce, and rice wine. }\end{array}$ & [17] \\
\hline $\begin{array}{l}\text { - Ginger extract } \\
\text { (GE) }\end{array}$ & $\begin{array}{c}\text { - Muscovy } \\
\text { duck } \\
\text { breast }\end{array}$ & 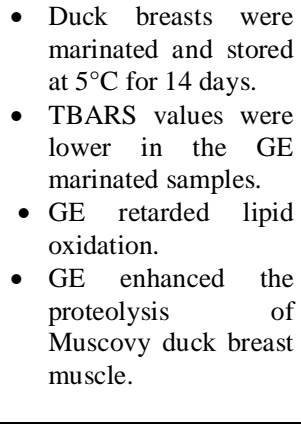 & {$[15]$} & 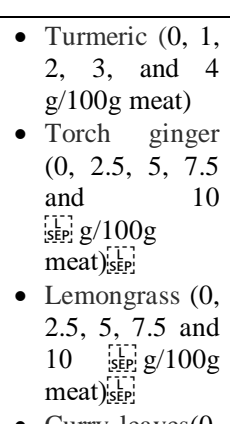 & $\begin{array}{c}\text { - Grilled } \\
\text { beef } \\
\text { (satay) }\end{array}$ & $\begin{array}{l}\text { - Turmeric is ireduced } \\
\text { maximum } 82 \mathrm{ng} / 100 \mathrm{~g} \\
\text { level of IQ at } 4 \\
\mathrm{~g} / 100 \mathrm{~g} \text { concentration } \\
\text { at medium doneness } \\
\text { and } 44.4 \text { ng/100g } \\
\text { level of it was } \\
\text { reduced of IQ, when } \\
\text { satay is } \\
\text { marinated with } 10 \\
\text { g/100g lemongrass } \\
\text { concentration at } \\
\text { medium aneness }\end{array}$ & [18] \\
\hline 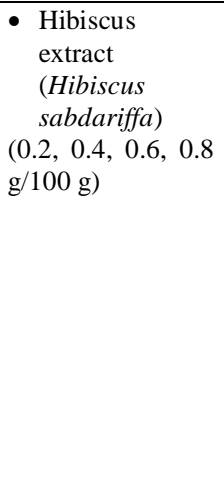 & $\begin{array}{l}\text { - } \begin{array}{l}\text { Fried } \\
\text { beef } \\
\text { patties }\end{array} \\
\text { pal }\end{array}$ & $\begin{array}{l}\text { - The concentration of } \\
\text { MeIQx was reduced } \\
\text { by about } 50 \% \text { and } \\
40 \% \text { by applying } \\
\text { marinades containing } \\
\text { the highest amount of } \\
\text { extract compared to } \\
\text { sunflower oil and } \\
\text { control marinade, } \\
\text { respectively. }\end{array}$ & [16] & 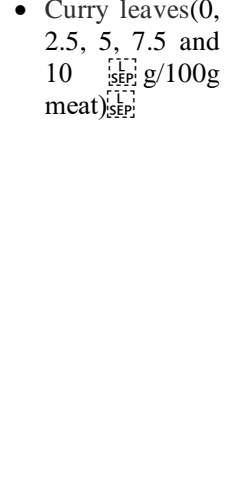 & & $\begin{array}{l}\text { medium doneness. } \\
\text { - The highest isteplevel } \\
\text { of } \\
\text { MeIQX was reduced } \\
\text { to } 83 \mathrm{ng} / 100 \mathrm{~g} \text { of } \\
\text { satay meat marinated } \\
\text { in } 10 \mathrm{~g} / 100 \mathrm{~g} \text { torch } \\
\text { ginger at medium } \\
\text { doneness. } \\
\text { Curry leaves with } 10 \\
\text { g/100g concentration } \\
\text { marinated beef } \\
\text { meatisepiwas reduced } \\
\text { the level of IQ } 78.5 \text { at } \\
\text { medium doneness. }\end{array}$ & \\
\hline
\end{tabular}


Published Online December 2019 in IJEAST (http://www.ijeast.com)

\begin{tabular}{|c|c|c|c|}
\hline 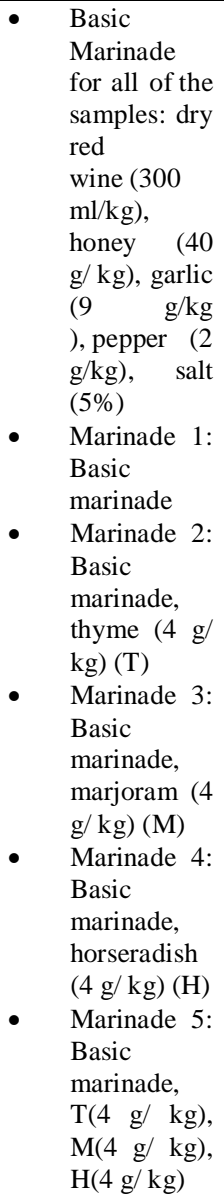 & - Beef & $\begin{array}{l}\text { - Beef was marinated } \\
\text { at } 4^{\circ} \mathrm{C} \text { for } 48 \text { hours. } \\
\text { - Storage at } 12 \text { days at } \\
5^{\circ} \mathrm{C} \text {. } \\
\text { - Marination (dry red } \\
\text { wine, salt, lime-tree } \\
\text { honey, thyme, } \\
\text { marjoram, garlic, } \\
\text { horseradish) } \\
\text { evidently controlled } \\
\text { total mesophilic } \\
\text { aerobic bacteria, } \\
\text { lactic acid bacteria } \\
\text { and oxidation of beef } \\
\text { meat. }\end{array}$ & [19] \\
\hline $\begin{array}{l}\text { - } \begin{array}{l}\text { Nanoparticle } \\
\text { paprika } \\
\text { oleoresin }(1 \\
\text { and } 3 \mathrm{~g} / 100 \\
\mathrm{~mL})\end{array} \\
\text { - }\end{array}$ & $\begin{array}{l}\text { Cooked } \\
\text { chicken }\end{array}$ &  & [1] \\
\hline
\end{tabular}




Published Online December 2019 in IJEAST (http://www.ijeast.com)

\begin{tabular}{|c|c|c|c|}
\hline  & Turkey & $\begin{array}{l}\text { - The turkey meat cuts } \\
\text { were marinated } \\
\text { overnight in plastic } \\
\text { boxes. } \\
\text { - Stored for } 7 \text { days in a } \\
\text { dark room at } 4^{\circ} \mathrm{C} \\
\text { - Meat from the } \\
\text { rosemary marinade } \\
\text { had the lowest } \\
\text { TBARS values and } \\
\text { volatile levels, while } \\
\text { the control samples } \\
\text { showed the highest } \\
\text { values throughout the } \\
\text { marinating, cooking } \\
\text { and storage period. } \\
\text { - Oxidative changes in } \\
\text { meat marinated with } \\
\text { thyme and sage were } \\
\text { significantly more } \\
\text { advanced than in } \\
\text { meat marinated with } \\
\text { rosemary decoction. } \\
\text { Antioxidants in herb } \\
\text { contained in in } \\
\text { decoction, could be } \\
\text { exploited turkey } \\
\text { marinades to prevent } \\
\text { rancidity in stored, } \\
\text { heat-treated turked } \\
\text { meat products. }\end{array}$ & {$[22]$} \\
\hline $\begin{array}{l}\text { - Lemon }(5 \mathrm{~mL}) \\
\text { - Greentea }(5 \mathrm{~mL}) \\
\text { - } \text { Turmeric }(5 \mathrm{~mL})\end{array}$ & - Chicken & $\begin{array}{l}\text { - Chicken was } \\
\text { marinated at } 4^{\circ} \mathrm{C} \text { for } \\
\text { various times }(0,1,6 \text {, } \\
12,24,36 \text { hours). } \\
\text { - A combination of } \\
\text { green tea, lemon and } \\
\text { turmeric was found to } \\
\text { be the most effective } \\
\text { against } C \text {. jejuni and } \\
S . \text { enteritidis }(12 \\
\text { hours). }\end{array}$ & [23] \\
\hline
\end{tabular}






\section{International Journal of Engineering Applied Sciences and Technology, 2019 \\ Vol. 4, Issue 8, ISSN No. 2455-2143, Pages 63-71 \\ Published Online December 2019 in IJEAST (http://www.ijeast.com)}

\section{USAGE OF ORGANIC ACIDS IN MEAT MARINATION}

Organic acids such as citric acid, lactic acid and acetic acid have high potency and are recommended because they do not have a health risk for consumers because they are already synthesized in natural environments. Organic acids dissociate when taken into the cell and reduce the intracellular $\mathrm{pH}$ and contribute to the production of more reliable and quality meat products. Depending on their use, the increase in water retention capacity is shaped, the solubility of meat proteins improves and sensory properties are improved. In addition to its contribution to meat quality, its antimicrobial effect against important pathogens also supports this widespread use [26].

$\mathrm{pH}$ significantly influences the Maillard reaction, so the simplest and low-cost method to stabilize the $\mathrm{pH}$ of the meat before the heat treatment could be marinating in a solution of an organic acid [27].

Citric acid, a food acidulante, is not only often used in acid marinating to improve the water-holding capacity and tenderness of beef muscle but is also commonly used as a chelator to control the activity of pro-oxidant metals. Lactic acid is often used in the meat industry as an antimicrobial agent [2].

Results of the studies on the use of organic acids in meat and meat products are given in Table 3 .

Table 3 Application of organic acids in meat marination

\begin{tabular}{|c|c|c|c|}
\hline Organic Acids & $\begin{array}{c}\text { Meat/Meat } \\
\text { Product } \\
\text { Tested }\end{array}$ & Results & References \\
\hline $\begin{array}{l}\text { Plum juice } \\
\text { concentrate } \\
\left(10^{\circ} \mathrm{Bx}-\right. \\
\left.14^{\circ} \mathrm{Bx}\right) \\
\text { - Apple juice } \\
\text { concentrate } \\
\left(10^{\circ} \mathrm{Bx}-\right. \\
\left.14^{\circ} \mathrm{Bx}\right)\end{array}$ & Chicken & $\begin{array}{l}\text { - } \text { Chicken was } \\
\text { marinated for } 36 \\
\text { hours at } 4^{\circ} \mathrm{C} \text {. } \\
\text { - } 14^{\circ} \mathrm{Bx} \text { apple } \\
\text { marination had } \\
\text { lowest thaw loss. } \\
\text { - } 10^{\circ} \mathrm{Bx} \text { apple } \\
\text { marination had } \\
\text { lowest cook loss. } \\
\text { - } 14^{\circ} \mathrm{Bx} \text { apple } \\
\text { marination had } \\
\text { highest general } \\
\text { choice value as a } \\
\text { parameter of } \\
\text { sensory analysis. }\end{array}$ & [14] \\
\hline $\begin{array}{l}\text { - Lactic acid } \\
(0.5 \%, 1 \% \text {, } \\
1.5 \%) \\
\text { - Citric acid } \\
(0.5 \%, 1 \%, \\
1.5 \%) \\
\end{array}$ & Beef & $\begin{array}{l}\text { - } \text { Marinated for } 72 \\
\text { hours at } 4^{\circ} \mathrm{C} \text {. } \\
\text { - } \text { Cooking loss was } \\
\text { lower in samples } \\
\text { marinated with } \\
\text { lactic acid }\end{array}$ & [28] \\
\hline
\end{tabular}

\begin{tabular}{|c|c|c|c|}
\hline & & $\begin{array}{l}\text { compared to citric } \\
\text { acid marinated } \\
\text { samples. }\end{array}$ & \\
\hline $\begin{array}{l}\text { - Citrus juice } \\
\text { (31\% orange } \\
\text { juice, } 31 \% \\
\text { lemon juice, } \\
38 \% \text { distilled } \\
\text { water) }\end{array}$ &  & $\begin{array}{l}\text { - } \text { Tenderisation of } \\
\text { beef samples } \\
\text { using a citrus juice } \\
\text { marinade was } \\
\text { observed. It could } \\
\text { be attributed to } \\
\text { marinade uptake } \\
\text { by muscle } \\
\text { proteins and also } \\
\text { to solubilisation of } \\
\text { collagen. }\end{array}$ & [29] \\
\hline $\begin{array}{l}\text { - Lactic acid } \\
\text { - Citric acid } \\
(0.5 \%, 1 \% \text { and } \\
1.5 \%)(1: 4 \mathrm{w} / \mathrm{v})\end{array}$ & -Beef &  & [30] \\
\hline
\end{tabular}

\section{CONCLUSION}

The functionality of the marinades varies entirely according to their compositions. Since spice and herbs have different health promoting properties their investigation as herbal additives is in great expansion. Usage of various forms of spices and herbs in meat marinates were searched and revealed that they increase shelf life, inhibit bacterial growth, diminish heterocyclic amin concentration, provide variety in product aroma and flavor, to establish a nice flavor balance. As a result of the studies, it was concluded that the use of different herbal additives and spices in combinations will promise. In addition to this, usage of different herbal additives with different ratios depend on meat sensory evaluation. Therefore, various combination studies are needed. In addition, the effect of used forms of herbal and spices should be taken into consideration.

\section{REFERENCE}

[1] Yusop, S. M., O’Sullivan, M. G., Preuß, M., Weber, H., Kerry, J. F. and Kerry, J. P. (2012). "Assessment of nanoparticle paprika oleoresin on marinating performance and sensory acceptance of poultry meat', Food Science and Technology, (pp. 349-355). 


\section{International Journal of Engineering Applied Sciences and Technology, 2019 \\ Vol. 4, Issue 8, ISSN No. 2455-2143, Pages 63-71 \\ Published Online December 2019 in IJEAST (http://www.ijeast.com)}

[2] Vlahova Vangelova, D. and Dragoev, S. (2014). "Marination: Effect on Meat Safety and Human Health. A review', Bulgarian Journal of Agricultural Science, 20(3), (pp. 503-509).

[3] Cabarkapa, I., Skrinjar, M., Blagojev, N., Gubic, J., Plavsic, D., Kokic, B. and Radusin, T. (2013). "Effect of Origanum heracleoticum L. Essential Oil on Marinated Chicken Meat Shelf-life', Journal of Pure and Applied Microbiology, (pp. 221-228).

[4] Arcanjo, N.M.O., Morcuende, D., Andrade, M.J., Padilla, P., Madruga, M.S. and Estevez, M. (2019). "Bioactivities of wine components on marinated beef during aging", Journal of Functional Foods, (pp. 19-30).

[5] Farhadian, A., Jinap, S., Faridah, A. and Zaidul, I.S.M. (2012). "Effects of marinating on the formation of polycyclic aromatic hydrocarbons (benzo[a]pyrene, benzo[b]fluoranthene and fluoranthene) in grilled beef meat', Food Control, (pp. 420-425).

[6] Jinap, S., Hasnol, N.D.S., Sanny, M. and Jahurul, M.H.A. (2018). "Effect of Organic Acid Ingredients in Marinades Containing Different Types of Sugar on the Formation of Heterocyclic Amines in Grilled Chicken', Food Control, (pp. 478-484).

[7] Aaslyng, M. D., Winther Lund, B. and Jensen, K. (2016). "Inhibition of Heterocyclic Aromatic Amines in Pork Chops Using Complex Marinades with Natural Antioxidants', Food and Nutrition Sciences, (pp. 13151329).

[8] Viegas, O., Novo, P., Pinto, E., Pinho, O., Ferreira, I.M. (2012). "Effect of charcoal types and grilling conditions on formation of heterocyclic aromatic amines (HAs) and polycyclic aromatic hydrocarbons (PAHs) in grilled muscle foods", Food Chem. Toxicol., (pp. 2128-2134).

[9] Haute, S. V., Raes, K., Van der Meeren, P., Sampers, I. (2016). "The effect of cinnamon, oregano and thyme essential oils in marinade on the microbial shelf life of fish and meat products', Food Control, (pp. 30-39).

[10] Karam, L., Roustom, R., Abiad, M. G., Obeid, T. E., Savvaidis, I. N. (2019). "Combined effects of thymol, carvacrol and packaging on the shelf-life of marinated chicken', International Journal of Food Microbiology, (pp. 42-47).

[11] Bakkali, F., Averbeck, S., Averbeck, D., \& Idaomar, M. (2008). "Biological effects of essential oils-a review", Food and Chemical Toxicology, (pp. 446-475).

[12] Vasilijević, B., Mitić-Ćulafić, D., Djekic, I., Marković, T., Knežević-Vukčević, J., Tomasevic, I., Velebit, B., Nikolić, B. (2019). "Antibacterial effect of Juniperus communis and Satureja montana essential oils against Listeria monocytogenes in vitro and in wine marinated beef', Food Control, (pp. 247-256).

[13] Rimini, S., Petracci, M., Smith, D. P. (2014). "The Use of Thyme and Orange Essential Oils Blend to Improve
Quality Traits of Marinated Chicken Meat', Poultry Science, (pp. 2096-2102).

[14] Erge, A., Cin, K. and Şeker, E. (2018). "Erik ve Elma Suyunun Tavuk Eti Marinasyonunda Kullanılması', The Journal of Food, (pp. 1040-1052).

[15] Thomas, R. H., Bernards, M. A., Drake, E. E. and Guglielmo, C. G. (2010). "Changes in the antioxidant activities of seven herb- and spice-based marinating sauces after cooking', Journal of Food Composition and Analysis, (pp. 244-252).

[16] İsmail, N. and Rosman, R. (2018). "Effects of Papaya Leaves Crude Extract on the Physicochemical and Sensory Characteristics of Marinated Chicken Meat', Scientific Research Journal, (pp. 35-50).

[17] Tsai, L. L., Yen, N.J., Chou, R. G. R. (2012). “Changes in Muscovy duck breast muscle marinated with ginger extract', Food Chemistry, (pp. 316-320).

[18] Gibis, M. and Weiss, J. (2010). "Inhibitory effect of marinades with hibiscus extract on formation heterocyclic aromatic amines and sensory quality of fried beef patties', Meat Science, (pp. 735-742).

[19] Wang, P., Hong, Y., Ke, W., Hu, X., Chen, F. (2017). "Formation of heterocyclic amines in Chinese marinated meat: effects of animal speciesisepiand ingredients (rock candy, soy sauce and rice wine)', J Sci Food Agric, (pp. 3967- 3978).

[20] Jinap, S., Iqbal, S. Z., Selvam, R. M. P. (2015). "Effect of Selected Local Spices Marinades on the Reduction of Heterocyclic Amines in Grilled Beef (satay)', LWTFood Science and Technology, (pp. 1-18).

[21] Istrati, D., Constantin, O., Ionescu, A., Vizireanu, C., Dinica, R. (2011). "Study of the Combined Effect of Spivces and Marination on Beef Meat Vakuum Packaged', The Annals of the University Dunarea de Jos of Galati Fascicle VI-Food Technology, (pp. 75-85).

[22] Mielnik, M. B., Sem, S., Egelandsdal, B., Skrede, G. (2008). "By-products from herbs essential oil production as ingredient in marinade for turkey thighs", LWT, (pp. 93-100).

[23] Murali, N., Kumar-Phillips, G.S., Rath, N.C., Marcy, J., Slavik, M.F. (2012). "Effect of Marinating Chicken Meat with Lemon, Green Tea and Turmeric Against Foodborne Bacterial Pathogens', International Journal of Poultry Science, (pp. 326-332).

[24] Moon, H., Kim, N. H., Kim, S. H., Kim, Y., Ryu, J. H. and Rhee, J. H. (2017). "Teriyaki sauce with carvacrol or thymol effectively controls Escherichia coli O157:H7, Listeria monocytogenes, Salmonella Typhimurium, and indigenous flora in marinated beef and marinade', Meat Science, (pp. 147-152).

[25] Hasnol, N.D., Jinap, S. and Sanny, M. (2014). "Effect of different types of sugars in a marinating formulation on 
the formation of heterocyclic amines in grilled chicken", Food Chemistry, (pp. 514-521).

[26] Kahraman, T., Bayraktaroğlu, A. G., Issa, G. and Aksu, F. (2010). "Bazı Organik Asitlerle Yapılan Marinasyon İşleminin Sığır Et Kalitesi Üzerine Etkisi’, İstanbul Üniv. Vet. Fak. Derg., (pp. 25-31).

[27] Biller, E., Boselli, E., Obiedzinski, M., Karpinski, P. and Waszkiewicz- Robak, B. (2016). "The profile of volatile compounds in the outer and inner parts of broiled pork neck is strongly influenced by the acetic-acid marination conditions", Meat Science, (pp. 292-301).

[28] Aktaş, N., Aksu, M. İ. and Kaya, M. (2003). "The Effect of Organic Acid Marination on Tenderness, Cooking Loss and Bound Water Content of Beef', Journal of Muscle Foods, (pp. 181-194).

[29] Burke, R. M. and Monahan, F. J. (2003). "The tenderisation of shin beef using a citrus juice marinade", Meat Science, (pp. 161-168).

[30] Hosseini, S. E. and Esfahani Mehr, A. (2015). "The effect of meat marinating with lactic and citric acid on some physicochemical and electrophoretic pattern of beef burger", Iranian Journal of Veterinary Medicine, (pp. 103-108). 